\title{
Effect of Pre-Wetting of High-Silica Sand on Parameters of Dried Moulding Sands Bonded with Selected Grades of Water-Glass
}

\author{
Mateusz Stachowicz, Kazimierz Granat, Lukasz Pałyga, Michał Kamiński \\ Department of Foundry Engineering, Plastics and Automation, Wrocław University of Technology, Wybr- \\ zeże Wyspiańskiego 25, 50-370 Wrocław, Poland. E-mail: mateusz.stachowicz@pwr.edu.pl
}

\begin{abstract}
Within the research, an attempt was made to determine influence of preliminary wetting of high-silica based ecofriendly moulding sands containing sodium water-glass on effectiveness of their hardening by traditional drying. Effectiveness of adding water to the base during stirring was evaluated by comparing mechanical and technological parameters after traditional drying at $100{ }^{\circ} \mathrm{C}$. Medium high-silica sand and two grades of hydrated sodium silicate 149 and 150 were used in the examinations. It was found that modification of preparation procedure by adding a proper quantity of water to high-silica base before adding binder (1.5 wt\%) favourably affects mechanical and technological parameters of hardened sandmix. Results of the measurements are correlated with SEM observations of links between base grains. On the grounds of complex evaluation of moulding sands hardened by traditional drying, a positive effect of water addition was found, especially in the sandmixes containing binder with higher viscosity, i.e. grade 149. Optimum quantity of water addition should be determined for each specific grade of binder.
\end{abstract}

Keywords: foundry sands, drying technology, water-glass, wetting, strength

\section{References}

[1] GRANAT, K., NOWAK, D., PIGIEL, M., STACHOWICZ, M., WIKIERA, R. (2007). The influence of hardening method on basic properties of water glass molding sands. In: Visnik Chmel'nickogo Nacional'nogo Universitetu, Vol. 4, No. 1, pp. $98-104$.

[2] GRANAT, K., NOWAK, D., PIGIEL, M., STACHOWICZ, M., WIKIERA, R. (2008). The influence of microwave heating and water glass kind on the properties of molding sands. In: Archives of Foundry Engineering, Vol. 8, Special No. 1, pp. 119-122.

[3] JINA, W., ZITIAN, F., XIAOLEI, Z., DI, P. (2009). Properties of sodium silicate bonded sand hardened by microwave heating. In: China Foundry, Vol. 6, No. 3, pp. 191-196.

[4] BALIŃSKI, A. (2002). Residual strength of molding a hydrated sodium silicate curing ethylene glycol diacetate in the light of the phase transition temperature and the resulting silica gel. In: Archiwum Technologii Maszyn $i$ Automatyzacji, Vol. 22, No.1, pp. 11-22.

[5] STACHOWICZ, M., GRANAT, K., PAŁYGA, Ł. (2016). Effect of sand wetting on physically hardened moulding sands containing a selected inorganic binder. Part 1. In: Archives of Foundry Engineering, Vol. 16, No. 1, pp. 7378 .

[6] STACHOWICZ, M., GRANAT, K., PAŁYGA, Ł. (2016). Effect of sand wetting on physically hardened moulding sands containing a selected inorganic binder. Part 2. In: Archives of Foundry Engineering, Vol. 16, No. 1, pp. 7984.

[7] STACHOWICZ, M., GRANAT, K., NOWAK, D. (2010). Studies on the possibility of more effective use of water glass thanks to application of selected methods of hardening. In: Archives of Foundry Engineering, Vol. 10, Special No. 2, pp. 135-140.

[8] STACHOWICZ, M., GRANAT, K., NOWAK, D., HAIMANN, K. (2013). Effect of hardening methods of moulding sands with water glass on structure of bonding bridges. In: Archives of Foundry Engineering, Vol. 10, No. 3 , pp. 123-128.

[9] GRANAT, K., NOWAK, D., PIGIEL, M., STACHOWICZ, M., WIKIERA, R. (2009). Determination of application possibilities of microwave heating in the curing process of water glass molding sands with fluid esters. Pt. 1. In: Archives of Foundry Engineering. Vol. 9, No. 1, pp. 45-50.

[10]MAJOR-GABRYŚ, K., DOBOSZ, S.M., JAKUBSKI J. (2013). Modified hydrated sodium silicate as a modern binder for ecological moulding sands. In: Manufacturing Technology, Vol. 13, No. 1, pp. 68 - 73.

[11]STACHOWICZ, M., GRANAT, K. (2014). Possibilities of reclamation microwave-hardened molding sands with water glass. In: Archives of Metallurgy and Materials, Vol. 59, No. 2, pp. 757-760. 
[12]STACHOWICZ, M., GRANAT, K. (2015). Influence of melt temperature on strength parameters of cyclically activated used-up sandmixes containing water-glass, hardened with microwaves, In: Archives Of Civil And Mechanical Engineering, 2015, Vol. 15, No. 4, pp. 831-835.

[13]HUTERA, B., SMYKSY, K., DROŻYŃSKI, D. (2007). Influence of lowered temperature on wettability of quartz grains by binders used in moulding sands. In: Archives of Mechanical Technology and Automation, Vol. 27, No. 1 , pp. 47-55.

[14]DOBOSZ, S.,M. (2006). Water in moulding and core sands, pp. 9 - 19, 123 - 136. Akapit Science Publisher, Kraków.

[15]BOBROWSKI, A., KMITA, A., STAROWICZ, M., STYPUŁA, B., HUTERA, B. (2012). Effect of Magnesium Oxide Nanoparticles on Water Glass Structure. In: Archives of Foundry Engineering, Vol. 12, No. 3, pp. 9 - 12.

Copyright (C) 2016. Published by Manufacturing Technology. All rights reserved. 